\title{
IMPLEMENTASI PENDIDIKAN ANTI KORUPSI MELALUI HABITUASI DAN PEMBELAJARAN PENDIDIKAN KEWARGANEGARAAN UNTUK MEMBANGUN KARAKTER SISWA DI SMP NEGERI 1 CIANJUR
}

\author{
Apiek Gandamana
}

Surel: apgan@unimed.ac.id

\begin{abstract}
This study generally aims to describe and analyzing in depth the implementation of anti-corruption education and learning through habituation Civics. Research process using a qualitative approach with descriptive methods. Results showed that the implementation of anti-corruption education is done by integrating anticorruption education material into Civics subject because when used as a separate subject would burden the students itself, the habituation performed by all people in schools environment that instill the values of honesty, and discipline, as well as a canteen of honesty as a form of students habituation to do what is right
\end{abstract}

Keywords: Anti-Corruption Education, Habituation, Character.

\begin{abstract}
ABSTRAK
Penelitian ini secara umum bertujuan untuk mendeskripsikan dan menganalisis secara mendalam implementasi pendidikan anti korupsi. Lokasi penelitian di SMP Negeri 1 Cianjur. Proses penelitian menggunakan pendekatan kualitatif dengan metode deskriptif. Hasil penelitian adalah model implementasi pendidikan anti korupsi dilakukan dengan 2 cara, yaitu mengintegrasikan materi pendidikan anti korupsi ke dalam mata pelajaran PKn dan model pembudayaan, pembiasaan nilai dalam seluruh aktivitas dan suasana sekolah. Faktor pendukung adalah adanya komitmen yang baik dari seluruh warga sekolah dan orang tua, serta adanya dukungan dari pemerintah. Sedangkan faktor penghambat yaitu kesulitan guru dalam mengintegrasikan pendidikan anti korupsi ke dalam mata pelajaran PKn serta faktor lingkungan yang melihat korupsi sebagai hal yang biasa atau membudaya.
\end{abstract}

Kata Kunci: Pendidikan Antikorupsi, Habituasi, dan Karakter.

\section{PENDAHULUAN}

Praktik kenegaraan dan politik selama ini telah bergelimang dengan ketidakjujuran dan kemunafikan. Ketidakjujuran itu menjelma dalam pelaksanaan profesi, tugas, atau pekerjaan yang penuh kelicikan dan kemunafikan hingga merebaknya

ketidakadilan. Dipertegas oleh pendapat Sutanto dalam Wibowo (2013: 9), menyatakan bahwa para ahli psikologi mengibaratkan sebagai sebuah pembicaraan yang tidak selesai-selesai dan pembicaraan sirkumstansial-dua simtom dari

problem ketidakjujuran telah merebaknya kerumitan, keruwetan, kepelikan, dan kesulitan luar biasa kompleks.

Korupsi yang terjadi di
Indonesia sudah $r$ sangat
mengkhawatirkan dan berdampak
buruk luar biasa pada hampir seluruh
sendi kehidupan. Korupsi telah
menghancurkan sistem
perekonomian, sistem demokrasi,


sistem politik, sistem hukum, sistem pemerintahan, dan tatanan sosial kemasyarakatan di negeri ini. Di lain pihak upaya pemberantasan korupsi yang telah dilakukan selama ini belum menunjukkan hasil yang optimal. Korupsi dalam berbagai tingkatan tetap saja banyak terjadi seolah-olah telah menjadi bagian dari kehidupan kita, bahkan sudah dianggap sebagai hal yang biasa. Jika kondisi ini tetap kita biarkan berlangsung maka cepat atau lambat korupsi akan menghancurkan negeri ini.

Pemberantasan korupsi melalui penegakan hukum masih belum cukup, tetapi harus diimbangi dengan menumbuhkan semangat, atmosfer, dan budaya anti korupsi. Semangat, atmosfer, dan budaya anti korupsi yang dimaksud dapat dilakukan melalui pendidikan formal. Hal ini karena salah satu fungsi pendidikan adalah untuk melakukan koreksi budaya (Eby, 1952; Darmawan, dkk, 2008; Hassan, 2004; Muhtari, 2004; Zuriah, 2008), yaitu koreksi terhadap budaya yang tidak baik atau kontraproduktif yang tumbuh dan berkembang dalam masyarakat. Termasuk di dalamnya mereduksi sikap dan perilaku korupsi dan menebalkan semangat antikorupsi khususnya kepada siswa sebagai generasi penerus bangsa. (Harmanto, 2012:3).

Beberapa hasil survey
lembaga-lembaga
mengindikasikan tingginya transparansi
korupsi di Indonesia, karena
Indonesia sendiri dibandingkan

dengan negara-negara lainnya, berada di posisi kelima terkorup di dunia menurut Survey Transparency International (TI) pada tahun 2009. Sedangkan untuk kalangan Asia, Indonesia menduduki sebagai negara terkorup nomor satu di Asia dengan nilai 8,32 dan dibawahnya Thailand dengan nilai 7,63.

\section{Menurut Tranparency} International tahun 2012 skor Indonesia adalah 32, pada urutan 118 dari 176 negara yang diukur. Indonesia sejajar posisinya dengan Republik Dominika, Ekuador, Mesir dan Madagaskar.

Dari beberapa hasil survey lembaga-lembaga anti korupsi menunjukkan Indonesia merupakan negara yang tinggi tingkat korupsinya. Apabila dibiarkan tidak mustahil korupsi di Indonesia bisa menjadi suatu budaya yang mengakibatkan rusaknya perekonomian, moral, hukum, pendidikan, dan lain sebagainya.

Menurut Sumiarti (2007: 2) menyatakan bahwa korupsi yang terjadi di Indonesia sudah mencapai taraf yang sangat memprihatinkan

dan jika dibiarkan akan menyebabkan bangsa dan negara Indonesia semakin terpuruk ke dalam jurang kemiskinan, kebodohan, dan keterbelakangan.

Salah satu wujud perhatian pemerintah terhadap bahaya korupsi adalah menetapkan kebijakan tentang pemberantasan korupsi yang dituangkan dalam Instruksi Presiden (Inpres) Nomor 5 tahun 2004 tentang Percepatan Pemberantasan Korupsi. 
Pada bagian Diktum ke-11 (Instruksi Khusus) poin ketujuh menugaskan kepada Menteri Pendidikan Nasional (sekarang Menteri Pendidikan dan Kebudayaan) untuk menyelenggarakan pendidikan yang bersubstansikan penanaman, semangat dan perilaku antikorupsi baik pada jenjang pendidikan formal maupun nonformal. Hal tersebut diperkuat dengan dikeluarkannya Instruksi Presiden (Inpres) Nomor 17 tahun 2011 tentang Aksi Pencegahan dan Pemberantasan Korupsi Tahun

2012. Handoyo (2007: 13) mengungkapkan bahwa: pendidikan anti korupsi adalah usaha sadar untuk memberi pemahaman dan mencegah terjadinya perbuatan korupsi yang dilakukan dalam proses pembelajaran di sekolah. Pendidikan anti korupsi akan lebih efektif apabila diterapkan pada masyarakat usia dini. Pendidikan anti korupsi pada dasarnya dapat dilakukan pada pendidikan informal di lingkungan keluarga, pendidikan nonformal, dan pendidikan formal pada jalur sekolah. Namun karena otoritas yang dimiliki dan kultur yang dipunyai, jalur formal atau sekolah dipandang lebih efektif untuk menyiapkan generasi muda berperilaku anti korupsi.

Senada dengan pendapat di atas, Djabbar dalam Annas (2011: 3) Materi pendidikan anti korupsi di sekolah tidak hanya sekedar pemberian wawasan di ranah kognitif (materi), tidak sekedar pemahaman dan menghafal. Lebih dari itu, pendidikan antikorupsi menyentuh pula ranah afektif dan psikomotorik. Membentuk sikap dan perilaku antikorupsi pada siswa. Menuju penghayatan dan pengamalan nilainilai antikorupsi.

\section{METODE}

PENELITIAN

Penelitian ini menggunakan

pendekatan kualitatif sementara metode yang digunakan dalam penelitian ini yaitu metode deskriptif analitis. Dalam penelitian ini dilakukan pengecekan validitas data melalui derajat keterpercayaan (credibility), keteralihan (tranferbility), ketergantungan (defendebility), dan kepastian (confirmabality).

Subjek dalam penelitian ini agar memperoleh informasi yang valid dan bertalian, maka yang menjadi subjek penelitiannya seperti terdapat dalam tabel berikut:

Tabel 1. Subjek Penelitian

\begin{tabular}{l|l|l}
\hline No & \multicolumn{1}{|c|}{ Informan } & \multicolumn{1}{|c}{ Jumlah } \\
\hline 1. & Kepala Sekolah & 1 orang \\
\hline 2. & Waka.Urusan Kesiswaan/Non Akademik & 1 orang \\
\hline 3. & Guru PKn & 2 orang \\
\hline 4. & Peserta Didik Kelas VII dan VIII & 10 orang \\
\hline \multicolumn{2}{c}{ Jumlah } & $\mathbf{1 4}$ orang \\
\hline
\end{tabular}


Apiek Gandamana : Implementasi Pendidikan Anti ...

Peneliti terjun langsung ke informasi/data melalui dokumentasi, observasi, dan wawancara. Dalam penelitian ini peneliti menggunakan pendekatan antar manusia, artinya selama proses penelitian peneliti akan lebih banyak mengadakan kontak dengan orang-orang sekitar lokasi penelitian yaitu di SMP Negeri 1 Cianjur. Dengan demikian peneliti lebih leluasa mencari informasi dan data yang terperinci tentang berbagai hal yang diperlukan untuk kepentingan penelitian.

Teknik pengumpulan data yang digunakan dalam penelitian ini adalah: (1) Observasi maksudnya dalam penelitian ini, peneliti terjun langsung ke lapangan untuk mengamati dan menyajikan secara

realistik informasi tentang implementasi pendidikan antikorupsi melalui habituasi dan pembelajaran PKn; (2) Wawancara, wawancara harus dilakukan oleh peneliti kepada subjek penelitian untuk memperoleh data yang diperlukan. Seorang peneliti dapat menggunakan wawancara sesuai dengan kondisi subjek yang terlibat dalam interaksi sosial yang dianggap memiliki pengetahuan yang memadai dan

mengetahui informasi yang dibutuhkan agar memperoleh data yang digunakan untuk menjawab fokus penelitian; (3) Studi literatur, mendapatkan data atau informasi

yang ada hubungannya dengan masalah yang akan diteliti dari bukubuku yang relevan; (4) Dokumentasi, data informasi sesuai dengan masalah penelitian seperti data statistik, data siswa, foto, dan surat-surat. Sementara itu analisis data yang digunakan dalam penelitian ini adalah analisis deskriptif.

\section{HASIL PENELITIAN DAN PEMBAHASAN}

Pembahasan penelitian ini merupakan hasil observasi, wawancara, serta studi dokumentasi yang dilakukan selama penelitian. Dari deskripsi dan interpretasi data tersebut dibahas untuk mengungkap essensi fenomena yang muncul dilapangan. Deskripsi dimaksudkan untuk menuangkan data objektif tentang segala sesuatu yang diamati dan didengar. Interpretasi dimaksudkan untuk memberikan makna, dengan jalan menyusun dan merakit unsur-unsur lama dengan cara memproyeksikannya. Karena itu materi yang disajikan bersifat "informartif dan reformatif", dalam arti telah diperlakukan sesuai dengan interpretasi konteks maupun konsep.

Untuk melengkapi data, maka peneliti juga melakukan proses wawancara dengan menggunakan teknik purposive dan snowball terhadap 14 narasumber kunci yang ditemui langsung di SMP Negeri 1 Cianjur. Narasumber yang berhasil di wawancara secara intensif oleh peneliti adalah UA pada hari Senin 29 April 2013; DK dan DJ dilaksanakan pada hari Selasa 30 April 2013; TS, AP, DR, AF, dan M dilaksanakan pada hari Kamis 02 Mei 2013; IS dilaksanakan pada hari 
Jumat 03 Mei 2013; MG, H, T, ST, dan A dilaksanakan hari Sabtu 04 Mei 2013.

Dari hasil observasi dan wawancara dihasilkan bahwa di SMP Negeri 1 Cianjur dalam mengimplementasikan pendidikan anti korupsi dilakukan dengan 2 model, yaitu model di dalam kelas dan di luar kelas. Di dalam kelas dengan cara mengintegrasikan materi pendidikan anti korupsi ke dalam materi mata pelajaran PKn. Sementara model di luar kelas dengan cara pembiasaan atau habituasi yaitu keteladanan dan adanya Kantin Kejujuran.

Faktor pendukung adanya implementasi pendidikan anti korupsi di SMP Negeri 1 Cianjur yaitu adanya dukungan yang baik dari Pemerintah Kabupaten Cianjur dan Kejaksaan Negeri Cianjur serta adanya komitmen yang kuat dari Kepala Sekolah, Guru, dan warga sekolah. Sementara faktor penghambat dari implementasi pendidikan antikorupsi yaitu Guru sebagai pelaksana program pendidikan anti korupsi masih kurang akan materi antikorupsi

\section{Pembahasan}

Pendidikan Anti Korupsi di SMP Negeri 1 Cianjur yang dilakukan secara konsisten dan berkelanjutan, akan menumbuhkan sebuah sikap yang menjadi kepribadian anak. Pada dasarnya sebuah kepribadian seseorang tidak muncul secara instan namun melalui sebuah proses. Begitu juga penanaman nilai-nilai anti korupsi terhadap siswa di sekolah SMP Negeri 1 Cianjur.

Dapat disimpulkan bahwa pendidikan anti korupsi di SMP Negeri 1 Cianjur menjadi sebuah langkah strategis bagi pencegahan korupsi, karena selama ini korupsi terus langgeng antara lain karena rendahnya tingkat pemahaman mengenai korupsi yang tidak saja menyebabkan kesalahpahaman mengenai bentuk-bentuk korupsi, namun juga menyeret seseorang terperangkap kedalam sistem yang mengakomodir perilaku korupsi tersebut. Pendidikan selama ini diyakini belum memberi penyadaran mengenai korupsi. Dengan demikian, sudah saatnya pendidikan anti korupsi diterapkan di semua lembaga pendidikan sebagai strategi awal

bagi pencegahan korupsi di Indonesia sedini mungkin.

Berdasarkan hasil wawancara dan observasi pelaksanaan pendidikan anti korupsi di SMP Negeri 1 Cianjur sebagaimana yang telah disajikan dalam penyajian

data. Guru mata pelajaran Pendidikan Kewarganegaraan, bahwa dalam mendidik siswanya berperilaku anti korupsi ialah dengan cara menelaah pokok-pokok bahasan mana yang bisa dimasukkan nilainilai anti korupsi dan dituangkan dalam RPP, sebab tidak semua materi yang diajarkan kepada siswa harus dimasukkan nilai-nilai anti korupsi. Dengan kalimat lain, guru Pendidikan 
Apiek Gandamana : Implementasi Pendidikan Anti ...

Kewarganegaraan mengatakan mengajari dan mendidik siswanya, manakala pokok bahasan yang

sedang dipelajari memiliki kaitan dengan pendidikan anti korupsi atau disisipkan pesan-pesan moral yang memiliki nilai-nilai anti korupsi dalam proses belajar mengajar.

Cara guru Pendidikan Kewarganegaraan mengajarkan siswa-siswanya dalam proses belajar mengajar dikelas hanya dengan menanamkan nilai-nilai pendidikan anti korupsi pada materi tertentu seperti dikatakan di atas dapatlah dimaklumi. Sebab seperti

telah dikatakan sebelumnya bahwa memang pendidikan anti korupsi tidak berdiri sendiri sebagai sebuah mata pelajaran khusus, melainkan hanya materi ajar yang diintegrasikan kepada mata pelajaran lain yang dalam hal

ini materi Pendidikan

Kewarganegaraan. Guru Pendidikan

Kewarganegaraan dalam menanamkan nilai-nilai antikorupsi seringkali memberikan contoh kasus korupsi yang merugikan masyarakat.

Hal ini sejalan dengan teori sibernika yang disampaikan Parsons (Craib, 1986:70) bahwa pendidikan anti korupsi di sekolah untuk mengembangkan fungsi internalisasi, sosialisasi, dan pelembagaan nilainilai antikorupsi. Nilai-nilai antikorupsi dikembangkan dalam perilaku warga sekolah, sistem kepribadian, sosial, dan budaya.
Sejalan dengan pendapat di atas, Wibowo (2013: 54) menyatakan bahwa, Nilai pendidikan anti korupsi bukanlah bahan ajar biasa. Nilai-nilai tersebut tidak dijadikan pokok bahasan yang harus disampaikan seperti halnya ketika mengajarkan suatu konsep, teori, prosedur, ataupun fakta seperti dalam mata pelajaran agama, Bahasa Indonesia, PKn, IPA, IPS, matematika, pendidikan jasmani dan kesehatan, seni, dan keterampilan. Dengan demikian, materi pelajaran biasa digunakan sebagai bahan atau media untuk mengembangkan nilai-nilai pendidikan antikorupsi tersebut.

Berdasarkan hasil wawancara dan observasi di SMP Negeri 1 Cianjur dalam penerapan pendidikan antikorupsi. Model pembelajaran pendidikan anti korupsi yang digunakan oleh SMP Negeri 1 Cianjur yaitu model pembelajaran di kelas (integrasi materi pendidikan anti korupsi ke dalam mata pelajaran PKn) dan di luar kelas (habituasi melalui keteladanan dan kantin kejujuran).

Penerapan pendidikan anti korupsi di SMP Negeri 1 Cianjur tidak dimasukan sebagai pokok bahasan, tetapi terintegrasi ke dalam mata pelajaran, pengembangan diri, dan budaya sekolah. Oleh karena itu, guru dan sekolah mengintegrasikan nilai-nilai yang dikembangkan dalam pendidikan antikorupsi ke dalam Kurikulum Tingkat Satuan Pendidikan (KTSP), silabus dan Rencana Program Pembelajaran (RPP) yang sudah ada. 


Pengembangan nilai-nilai
pendidikan anti korupsi
diintegrasikan dalam setiap pokok
bahasan dari setiap mata pelajaran.
Nilai-nilai tersebut dicantumkan
dalam silabus dan RPP.
Pengembangan nilai-nilai pendidikan
anti korupsi di SMP Negeri 1 Cianjur
dalam silabus ditempuh melalui cara-
cara berikut ini:
a. mengidentifikasi
Kompetensi
Kompetensi Dasar (KD) yang
akan menjadi
pengintegrasian materi
antikorupsi; pendidikan
b. menambahkan indikator tentang
korupsi pada kolom indikator;
c. menambahkan materi pokok
tentang korupsi pada kolom
materi pokok sesuai dengan
indikatornya;
d. menyisipkan instrumen yang
berkaitan dengan korupsi untuk
mengevaluasi pelaksanaan
pendidikan antikorupsi; dan
e. menambahkan sumber belajar
(SB) tentang korupsi.

Sementara prosedur pengintergrasian pendidikan anti korupsi ke dalam RPP, diantaranya:

a. menyisipkan indikator materi pendidikan antikorupsi ;

b. menyisipkan materi pendidikan antikorupsi pada tujuan pembelajaran;

c. menguraikan indikator materi pendidikan antikorupsi pada materi pembelajaran; d. merencanakan pemberian materi pendidikan anti korupsi dalam langkah- langkah pembelajaran;

e. menambahkan sumber belajar; dan

f. menyisipakan instrumen tentang materi pendidikan anti korupsi dalam penilaian pelajaran.

Keunggulan model terintegrasi yaitu semua guru ikut bertanggung jawab akan penanaman nilai-nilai anti korupsi kepada siswa. Pemahaman nilai hidup anti korupsi dalam diri anak tidak melulu bersifat informatif-kognitif, melainkan bersifat terapan pada tiap mata pelajaran (Suparno, 2002: 43).

Dari hasil wawancara, observasi dan studi dokumentasi didapatkan data bahwa pendidikan anti korupsi di SMP Negeri 1 Cianjur belum cukup hanya diintegrasikan dalam pembelajaran Pendidikan Kewarganegaraan. Masih diperlukan habituasi yang dikemas dalam bentuk budaya sekolah. Budaya

sekolah tersebut antara lain keteladanan dan kantin kejujuran.

Hasil wawancara dan observasi

dilapangan habituasi atau pembiasaan yang diterapkan oleh SMP Negeri 1 Cianjur berupa keteladanan. Keteladanan Kepala Sekolah dan guru akan lebih efektif untuk membentuk karakter siswa. Keteladanan yang diterapkan di SMP Negeri 1 Cianjur contohnya, guru melarang siswa merokok begitupun guru di SMP Negeri 1 Cianjur tidak merokok di lingkungan sekolah. 
Apiek Gandamana : Implementasi Pendidikan Anti ...

Hasil tersebut diungkap lebih jauh oleh Sanjaya (2006: 179) yang menyatakan bahwa proses penanaman nilai-nilai anti korupsi kepada anak melalui proses keteladanan pada mulanya dilakukan secara mencontoh, namun anak perlu diberi pemahaman mengapa hal itu dilakukan. Misalnya, guru perlu menjelaskan mengapa kita tidak boleh korupsi; menjelaskan bahaya dari tindakan korupsi atau mengapa kita harus jujur, tidak mencontek pada waktu ulangan. Hal ini diperlukan agar sikap tertentu yang muncul benar-benar didasari oleh suatu keyakinan kebenaran sebagai suatu sistem nilai. Menurut penelitian yang dilakukan Harmanto (2008),diketahui bahwa keteladanan guru dan budaya sekolah memberikan kontribusi yang besar dalam menanamkan pola pikir, sikap dan tindakan pendidikan antikorupsi.

Selain keteladanan penerapan pendidikan anti korupsi di SMP Negeri 1 Cianjur menggunakan program kantin kejujuran. Ide dasar penyelenggaraannya adalah gagasan bersama antara Kejaksaan Negeri Cianjur, dan Pemerintah Kabupaten Cianjur yang direspon dan didukung oleh OKP dan SKPD di bawahnya. Tujuan kantin kejujuran SMP Negeri 1 Cianjur adalah sebagai pembelajaran melalui pembiasaan dalam merevitalisasi dan mengaktualisasi sifat kejujuran sebagai salah satu unsur utama mengantarkan pribadi-pribadi ke jenjang kehidupan yang sukses, kebahagiaan yang hakiki, dan kemakmuran yang abadi.

$$
\text { Dari hasil wawancara, }
$$
observasi, dan dokumentasi ditemukan bahwa kantin kejujuran di SMP Negeri 1 Cianjur menggunakan sistem terbuka. Program kantin kejujuran yang diselenggarakan di SMP Negeri 1 Cianjur dikelola secara langsung oleh team pembantu kepala sekolah (PKS) urusan kesiswaan. Pengelolaan tersebut meliputi membuka dan menutup kantin, mencatat dan menempel label harga, merapikan barang

dagangan dan mencatat pembukuan. Program kantin kejujuran menanamkan dan membiasakan nilai-nilai anti korupsi kepada siswa. Nilai anti korupsi bukan hanya kejujuran, tetapi juga tanggung jawab, kemandirian, kedisiplinan, keberanian, keadilan, kesederhanaan, kerja keras dan tidak korupsi. Pengelolaan yang langsung ditangani oleh team pembantu kepala sekolah (PKS)

urusan kesiswaan akan menghambat proses penanaman dan pembiasaan nilai-nilai sikap anti korupsi lainnya.

Temuan penelitian menunjukkan bahwa ada dua faktor dalam mendukung keberhasilan pendidikan anti korupsi di SMP Negeri 1 Cianjur, yaitu faktor internal dan eksternal. Faktor internal, pertama adanya keinginan yang kuat dari pihak sekolah untuk menerapkan pendidikan anti korupsi. Guru mempunyai peran dan fungsi sangat penting dalam upaya 
penanaman pendidikan antikorupsi. Guru yang baik adalah guru yang selain bisa memberi teori atau materi pelajaran, juga bisa memberikan contoh yang baik bagi siswa.

Kedua, adanya komitmen yang kuat dari kepala sekolah untuk menerapkan pendidikan anti korupsi. Kepala Sekolah merupakan orang yang mempunyai kewenangan paling tinggi dalam menentukan kebijakan sekolah. Berjalan tidaknya organisasi sekolah termasuk baik buruk kegiatan pembelajaran, prestasi, dan kegiatan-kegiatan lain di lingkungan sekolah salah satunya ditentukan oleh kebijakan kepala sekolah. Kepala sekolah mempunyai peran dalam upaya menanamkan pendidikan anti korupsi dalam

pembelajaran Pendidikan Kewarganegaraan. Dukungan dan komitmen dari kepala sekolah sangat dibutuhkan dalam hal mengeluarkan kebijakan terkait pelaksanaan pendidikan anti korupsi seperti: peraturan tentang tata tertib siswa, peraturan tentang tata tertib guru,

kebijakan tentang proses pembelajaran, kebijakan jam masuk dan pulang sekolah, dan lain

sebagainya. Dengan adanya dukungan dari kepala sekolah, guru akan sangat terbantu dalam menanamkan nilai-nilai antikorupsi kepada siswa, sehingga pendidikan anti korupsi dapat diajarkan dan dilaksanakan dengan baik.

Sedangkan faktor eksternal berupa adanya dukungan dari pihak luar dalam penerapan pendidikan anti korupsi di SMP Negeri 1 Cianjur.
Dukungan tersebut diberikan oleh Pemerintah Kabupaten Cianjur, Kejaksaan Negeri Cianjur, dan Komite Sekolah.

Hasil wawancara dan observasi faktor yang menghambat penerapan pendidikan anti korupsi di SMP Negeri Cianjur tediri dari dua faktor yaitu, faktor internal dan eksternal. Faktor internal atara lain :

a. Guru PKn mengalami kesulitan dalam pengintegrasian pendidikan anti korupsi karena kekurangtelitiandalam mengindentifakasi Standar Kompetensi.

b. Guru mengalami kesulitan dalam penyusunan silabus dan RPP PKn yang memuat materi pendidikan anti korupsi karena sebelum membuat silabus dan RPP guru harus memikirkan materi pendidikan apa yang dimasukkan dalam silabus dan RPP serta banyaknya komponen yang harus memuat pendidikan antikorupsi mulai dari indikator, tujuan pembelajaran, materi pembelajaran, langkah-langkah pembelajaran dan evaluasinya.

c. Gurumengalamikesulitan dalam pembagian waktu pembelajaran pendidikan anti korupsi karena materi PKn sudah penuh dan alokasi waktu pembelajaran PKn yang sedikit hanya 2 x 40 menit per minggu.

Sementara faktor eksternal yaitu masih adanya perilaku koruptif yang menganggap korupsi sebagai hak yang biasa. Kebiasaan perilaku koruptif yang dilakukan siswa seperti 
Apiek Gandamana : Implementasi Pendidikan Anti ...

menyontek saat ulangan atau mengerjakan tugas, datang terlambat, tidak mematuhi aturan, dan sebagainya menjadi penghambat dalam pelaksanaan pendidikan anti korupsi. Meskipun sudah diajarkan dalam mata pelajaran PKn serta selalu disinggung dalam berbagai kegiatan sekolah seperti upacara bendera, ternyata masih ada beberapa siswa yang masih sering melakukan perilaku koruptif.

Berdasarkan temuan hasil temuan penelitian, solusi untuk mengatasi hambatan implementasi pendidikan antikorupsi diantaranya:

a. sekolah harus lebih memberikan kesempatan kepada guru untuk mengikuti seminar ataupun pelatihan tentang pembelajaran pendidikan anti korupsi agar guru memiliki pengetahuan yang luas.

b. guru lebih sering mempelajari pendidikan anti korupsi agar mengalami kemudahan dalam pengintegrasian pendidikan antikorupsi ke dalam silabus maupun RPP PKn yang memuat pendidikan antikorupsi.

c. guru harus pandai memanfaatkan waktu secara efektif dengan menggunakan metode pembelajaran yang bisa mencakup semua materi baik materi PKn maupun materi pendidikan anti korupsi.

Sementara solusi untuk faktor eksternal yaitu pembiasaan perilaku koruptif. Setelah siswa mengetahui tentang apa itu korupsi dan bahayanya melalui sosialisasi yang dilaksanakan sekolah, maka siswa dapat mengetahui mana perbuatan yang mengandung unsur koruptif dan mana perbuatan yang bukan termasuk koruptif. Dengan pengetahuan siswa yang semakin banyak tentang pendidikan anti korupsi, maka akan berdampak pada sikap dan perilaku siswa yang menuju ke arah positif. Pembiasaan perilaku positif seperti kejujuran, kedisiplinan, keterbukaan, dan tanggung jawab harus terus dilakukan sehingga membentuk suatu karakter kepribadian siswa yang anti korupsi.

Hal tersebut sejalan dengan pendapat Yuwono (2008), penanaman pendidikan anti korupsi dapat dilakukan melalui: $\begin{array}{ll}\text { (1) Curriculum, } & \text { (2) The Ritual }\end{array}$ Life (3) Teachers. Curriculum berarti materi antikorupsi diajarkan lewat jalur pendidikan dengan memasukkan dalam materi mata pelajaran. The Ritual Life berarti nilai-nilai anti korupsi harus dibiasakan dalam kehidupan seharihari, sedangkan teachers berarti guru tidak hanya memberikan teori saja, tetapi juga contoh kepada siswanya.

\section{SIMPULAN}

Model pendidikan anti korupsi di SMP Negeri 1 Cianjur yaitu dengan model di dalam kelas berupa integrasi materi pendidikan anti korupsi ke dalam mata pelajaran PKn, dan model di luar kelas berupa keteladanan serta kantin kejujuran.Faktor pendukung pendidikan anti korupsi di SMP 
Negeri 1 Cianjur yaitu dibagi menjadi faktor internal dan eksternal. Faktor internal meliputi, adanya dukungan yang kuat dari kepala sekolah untuk menerapkan pendidikan anti korupsi dan adanya komitmen dari para guru khususnya guru PKn untuk melaksanakan pendidikan anti korupsi. Sedangkan faktor eksternal meliputi, adanya dukungan dari pihak luar yaitu Pemerintah Kabupaten Cianjur,

Dinas Pendidikan Kabupaten

Cianjur, dan Kejaksaan Negeri Cianjur.

Faktor penghambat pendidikan anti korupsi di SMP Negeri 1 Cianjur yaitu dibagi menjadi faktor internal dan eksternal. Faktor internal meliputi, guru PKn mengalami kesulitan dalam mengintegrasikan materi pendidikan anti korupsi ke dalam mata pelajaran PKn dan kurangnya waktu pembelajaran karena jam mata pelajaran PKn hanya 2 x 40 menit per minggu. Sedangkan faktor eksternal meliputi, masih adanya perilaku koruptif yang menganggap korupsi sebagai hal yang biasa.

Solusi untuk mengatasi kendala atau hambatan tersebut yaitu, guru harus diberikan kesempatan untuk mengikuti pelatihan pendidikan anti korupsi dan guru harus mempunyai keinginan serta komitmen yang kuat untuk belajar materi pendidikan anti korupsi. Dan adanya komitmem yang kuat dari seluruh warga sekolah dan juga pemerintah dalam rangka mendukung implementasi pendidikan anti korupsi tersebut.

\section{DAFTAR RUJUKAN}

Arikunto. Suharsimi. 2002. Prosedur Penelitian (Suatu Pendekatan Praktek). Jakarta: PT. Rineka Cipta.

Budimansyah, D. 2010. Penguatan Pendidikan Kewarganegaraan untuk Membangun Karakter Bangsa. Bandung: Widya Aksara Press.

Chaerudin, dkk. 2008. Strategi Pencegahan dan Penegakan

Hukum Tindak Pidana Korupsi. Bandung: Refika Aditama.

Chrisiana, W. 2005. "Upaya Penerapan Pendidikan Karakter Bagi Mahasiswa (Studi Kasus di Jurusan Teknik Industri Uk Petra)". Jurnal Teknik Industri. 7, (1), 83-88.

Dewiyani, M.J.S. 2011. "Menanamkan Pendidikan Karakter Berbasis Perbedaan Tipe Kepribadian Pada Mata

Kuliah Matriks Dan

Tranformasi Linier di Stikom Surabaya”. Jurnal Edumatica. $1,(2), 25-34$.

Dwiputrianti, S. 2009. "Memahami Strategi Pemberantasan Korupsi di Indonesia”. Jurnal Ilmu Administrasi. VI, (3), 241253.

Elvandari, S. et al. 2008. "Menumbuhkan Nilai-Nilai Anti Korupsi dalam Keluarga". Jurnal Warta Pengabdian Andalas, XIV, 143-152. 
Apiek Gandamana : Implementasi Pendidikan Anti ...

Fauzan, M. et al. 2012. "Implementasi Pemerintahan Yang Bersih Dalam Kerangka Rencana Aksi Daerah Pemberantasan Korupsi”. Jurnal Dinamika Hukum, 12, (3), 448-463.

Hakim, L. 2012. "Model Integrasi Pendidikan Anti Korupsi Dalam Kurikulum Pendidikan Islam". Jurnal Pendidikan Agama Islam-Ta'lim. 10, (2), 141-154.

Harmanto.(2012). Pengintegrasian Pendidikan Anti Korupsi dalam Pembelajaran PKn Sebagai Penguat Karakter Bangsa (Studi Evaluasi Pengembangan

Perangkat Pembelajaran Bermodel PAKEM di Sekolah Menengah Pertama). Disertasi pada Sekolah Pasca Sarjana UPI: tidak diterbitkan.

Harmanto \& Yudiani, Djunaida Dewi. 2009. "Pengintegrasian Pendidikan Antikorupsi Melalui Pembelajaran PKn dan Budaya Sekolah”. Jurnal CIVICUS.

Muhlisin. 2012. Efektivitas Penerapan Pendidikan Anti Korupsi Dalam

Pembudayaan Karakter

Jujur (Studi Kasus Di SMP

Kanisius Keluarga Kudus). Disertasi pada Sekolah Pasca Sarjana UPI: tidak diterbitkan.

Kesuma D., Darmawan C., Permana

J. 2008. Korupsi dan PendidikanAnti Korupsi, Bandung: Pustaka Aulia Press.
Komariah, Kokom St. 2011. "Model Pendidikan Nilai Moral Bagi Para Remaja Menurut Perspektif Islam". Jurnal Pendidikan Agama IslamTa'lim. 9, (1), 45-54.

Komalasari, K., Budimansyah, D. $2008 . \quad$ "Pengaruh Pembelajaran Kontekstual dalam Pendidikan Kewarganegaraan Siswa SMP". Jurnal Acta Civicus Pendidikan Kewarganegaraan, 2, (1).

Klitgaard, Robert, Ronald MacleanAbaroa dan H. Lindsey Parris. (2005).

Penuntun Pemberantasan Korupsi dalam Pemerintahan Daerah. Terjemahan Masri Maris. Jakarta: Yayasan Obor Indonesia.

Laksmi. 2006. "Information Literacy Pada LSM Indonesia Corruption Watch Dalam Membongkar Informasi Tentang Korupsi”. Jurnal Ilmu Informasi, Perpustakaan, dan Kearsipan. 1, (2), 1-25.

Melisa, Depiyanti, O. 2012. "Model

Pendidikan Karakter Di Islamic Full Day School". Jurnal Tarbawi, 1, (3), 221233.

Sapriya. 2007. Perspektif Pendidikan Kewarganegaraan sebagai Pendidikan Karakter Menurut Para Ahli. Bandung: Sekolah Pasca Sarjana UPI.

Sulistiani. 2012. Penanaman NilaiNilai Anti Korupsi Dalam Pendidikan Di MTS Al-Asror 
Patemon Gunungati

Semarang. Tesis pada Universitas Negeri Semarang: tidak diterbitkan.

Sumintono, B. et al. 2012. "Pendidikan Moral di Malaysia: Tantangan dan Implementasi Pendidikan Karakter di Sekolah". Jurnal Pendidikan Karakter. II, (1), 14-22.

Sumiarti. 2007. "Pendidikan Anti Korupsi”. Jurnal Insania. 12, (2), $1-13$.

Supardan, D. 2009. "Anatomi Korupsi dalam Perspektif Ilmu-ilmu Sosial di Indonesia”. Jurnal of Historical Studies, X, (1), 113-129.

Tri Rejeki, A. 2010. "Model Pembelajaran Nilai Kejujuran Melalui Budaya Malu Pada Anak Usia SD”. Jurnal Penelitian Inovasi dan
Perekayasa Pendidikan. 2, (1), 297-322.

Umar, H. 2012. "Pengawasan Untuk Pemberantasan Korupsi”. Jurnal Akuntansi dan Auditing. 8, (2), 109-121.

Walid, M. 2011. "Model Pendidikan Karakter Di Perguruan Tinggi Agama Islam (Studi tentang Pendidikan Karakter Berbasis Ulul albab di Universitas Islam Negeri Maulana Malik Ibrahim Malang)". Jurnal el-Qudwah. 1, (5), 115-154.

Wibowo, Agus. 2013. Pendidikan Antikorupsi di Sekolah Strategi Internalisasi Pendidikan Antikorupsi di Sekolah. Yogyakarta: Pustaka Pelajar. Yudia Fauzi, F. 2013. "Peran Guru Pendidikan Pancasila dan Kewarganegaraan Dalam Upaya Pembentukan Karakter Peserta Didik". Jurnal PPKN UNJ Online. 1, (2), 1-15. 